Original Article

\title{
BLACK CUMIN (NIGELLA SATIVA) EFFECT ON BLOOD PRESSURE, MEAN ARTERIAL PRESSURE, PROTEINURIA IN PREECLAMPTIC MODEL RATS
}

\author{
JOHNY MARPAUNG ${ }^{1}$, M. F. G. SIREGAR², MAKMUR SITEPU' ${ }^{1}$, ADANG BACHTIAR ${ }^{3}$
}

1Department of Obstetric and Gynaecology, Medical Faculty, Universitas Sumatera Utara, General Hospital H. Adam Malik Medan, ${ }^{2}$ Fertility Endocrinology Division, President of Persatuan Menopause Indonesia (PERMI), Department of Obstetric and Gynaecology, Medical Faculty, Universitas Sumatera Utara, General Hospital H. Adam Malik Medan, ${ }^{3}$ Public Health Department, Medical Faculty, Universitas Indonesia

Email: drjohnymarpaung@gmail.com

Received: 25 Mar 2020, Revised and Accepted: 27 May 2020

\begin{abstract}
Objective: This research aimed to show effect of black cumin (nigella sativa) on blood pressure, mean arterial pressure (MAP), proteinuria in preeclamptic model rats.

Methods: This is analytical research with true experimental design in laboratory pregnant female rats (Rattus norvegicus), which get black cumin seed extract (Nigella sativa) at a dose of $500 \mathrm{mg} / \mathrm{kg} /$ day and $2000 \mathrm{mg} / \mathrm{kg} /$ day. Treatment of all samples was performed simultaneously and during the treatment was observed using Postest Only Control Group Design. The research was conducted at Biology Laboratory in July 2019. To assess the comparison of parameters (systolic and diastolic blood pressure, mean arterial pressure and proteinuria) between groups the ANOVA test was used if the data were normally distributed and Kruskal Wallis test was used if the data were abnormally distributed.
\end{abstract}

Results: Systolic and diastolic blood pressure and MAP decreased in preeclampsia models rats by administering $500 \mathrm{mg}$ (P1) and $2000 \mathrm{mg}$ (cumin) black cumin extract (P2). However, a dose of $2000 \mathrm{mg}$ black cumin extract had a more significant decrease in systolic blood pressure and MAP. The results of this research indicate that all treatment groups showed improvement after day 9 of the administration of nigella that no treatment group showed proteinuria.

Conclusion: Black cumin is proven to reduce systolic and diastolic blood pressure, Mean Arterial Pressure and proteinuria.

Keywords: Black cumin, Systolic, Diastolic, Mean arterial pressure, Proteinuria

(C) 2020 The Authors. Published by Innovare Academic Sciences Pvt Ltd. This is an open access article under the CC BY license (http://creativecommons.org/licenses/by/4.0/) DOI: http://dx.doi.org/10.22159/ijcpr.2020v12i4.39099. Journal homepage: https://innovareacademics.in/journals/index.php/ijcpr

\section{INTRODUCTION}

Based on the Republic of Indonesia Health Profile in 2017 issued by the Ministry of Health, the maternal mortality rate is 305 per 100,000 live births [1]. According to Banten Study II in 2015-2017, 19.1\% maternal mortality was due to preeclampsia (PE) or eclampsia [2].

Preeclampsia (PE) is a pregnancy disorder characterized by systemic hypertension and endothelial dysfunction [3]. PE is hypertension (systolic blood pressure $\geq 140 \mathrm{mmHg}$ or diastolic blood pressure $\geq 90 \mathrm{~mm} \mathrm{Hg}$ ) arising after $20 \mathrm{w}^{\prime}$ gestation with or without proteinuria (300 mg or more, in 24 hour urine capacity) [4]. In Indonesia, PE prevalence data are still limited, especially data at the national level. Even so, the incidence of PE is around 3-10\% [5].

Oxidative stress plays an integral part of the aging process and results from the overproduction of free radicals such as reactive oxygen species (ROS), which overwhelm the body's antioxidant defense mechanisms. Normally, antioxidants neutralize ROS and thus help to prevent overexposure from oxidative stress. However, as the body ages, antioxidant levels decline, leaving the human body susceptible to a variety of age-related pathologies, such as nonalcoholic liver cirrhosis and atherosclerotic heart disease. This decline combined with a gradual loss of estrogen in the female reproductive system is highly associated with the various sequelae of menopause [6]. Deficiency of estrogen in menopause causes increase of free radicals and oxidative stress which will trigger dNA apoptosis in whole cells. Lypoperoxidase level was higher in postmenopausal women compared with premenopausal $(0,357 \pm 0,05$ vs $0.331 \pm 0.05 \mathrm{mmol} / \mathrm{l} ; \mathrm{p}<0.001)$. Study by MFG Siregar concluded women in menopause experienced higher oxidative stresss compared to reproductive women. This condition is similar to preeclampsia condition [7].
In recent years, began to develop drugs from herbs, one of which is Nigella sativa (plant of the ranunculaceae family). Black cumin has efficacy as an antioxidant that quite strong and can reduce blood pressure. Thymoquinone, dithymoquinone, and thymol contained in black cumin seed oil can reduce free radicals and act as an antihypertensive agent $[8,9]$.

Rattus norvegicus strain rat are one of the animals that are widely used as experimental animals [10]. This is because these rat have a hemocorial placenta type that is similar to humans and the placenta displays intrusion of the interstitial and endovascular trophoblasts and remodeling of the maternal artery even though it is smaller than humans [11].

Besides directly inhibiting inflammatory mediators, intravenous Nigella sativa administration in rats with dose-dependent 4-32 $\mu \mathrm{g} / \mathrm{kgBW}$ can reduce arteriolar blood pressure and pulse rate. This can occur because of the content of Nigella sativa acting on serotonergic and muscarinic receptors [12]. With a daily dose of 2.5 $\mathrm{mg} / \mathrm{kg}$ body weight given for $8 \mathrm{w}$ in hypertensive model rats, systolic blood pressure (TDS) can be significantly reduced $(\mathrm{p}<0.05)$. The decrease (TDS) was followed by a decrease in oxidase activity through Angiotensin-Converting Enzyme (ACE) and nicotinamide adenine dinucleotide phosphate hydrogen (NADPH) significantly $(p<0.05)$. Oral administration of thymoquinone to Nigella sativa at a daily dose of $1 \mathrm{mg} / \mathrm{kgBB}$ can reduce high blood pressure in hypertensive animals with L-NAME induction. In addition, kidney damage is also reduced with thymoquinone [13].

\section{MATERIALS AND METHODS}

This is analytical research with true experimental design in laboratory pregnant female rats (Rattus norvegicus) which given black cumin seed extract (Nigella sativa) at a dose of $500 \mathrm{mg} / \mathrm{kg} / \mathrm{d}$ and $2000 \mathrm{mg} / \mathrm{kg} / \mathrm{d}$. The treatment of all samples was carried out 
simultaneously and during the treatment was observed using Postest Only Control Group Design.

The research was conducted at Biology Laboratory of USU Mathematics and Natural Sciences Faculty, starting the process of acclimatization, treatment and sampling of experimental animals which was held in July 2019. The number of treatment groups was 4 groups, so that the total sample was 24 animals.

\section{Work arrangement}

Rattus norvegicus-10-week-old female rats were kept in cages with sufficient moisture and light. Then female and male Rattus norvegicus rats were put together in one cage and kept for one night at a ratio of 1: 1 . The diagnosis of pregnancy is obtained by the presence of vaginal spermatozoa/vaginal plugs and counted as pregnancy day 0 . Pregnant female Rattus norvegicus rats are grouped into 4 groups randomly. The injection that used to make the PE rat model is LPS (lipopolysaccharide) with a daily dose of $0.5 \mu \mathrm{g} / \mathrm{kg}$ (Escherichia coli serotype 0111: B4, Sigma-Aldrich), diluted in $2 \mathrm{ml}$ of saline solution. The parameters of the PE model rats used in this research include systolic blood pressure of $124.89 \pm 1.79 \mathrm{mmHg}$ and Proteuria levels of $2.02 \pm 0.29 \mathrm{mg} / \mathrm{dl}$. Black cumin seed extract (Nigella sativa) is given orally through oral gavage and is prepared as needed.

Group 1, negative control (normal), pregnant rats were not given any treatment in general, only given excessive food and drink (adlibitum) in their cages. Group 2, the treatment group were pregnant rats given LPS injection on the $5^{\text {thand }} 8^{\text {th }}$ day of pregnancy when trophoblast invasion was started, so that they became PE model rats but were not given black cumin seed extract (Nigella sativa). Group 3, the treatment group namely pregnant rats given LPS injection and given black cumin seed extract (Nigella sativa) at a dose of $500 \mathrm{mg} / \mathrm{kgBW} /$ day for $15 \mathrm{~d}$. Group 4, the treatment group was pregnant rats given LPS injection and given black cumin seed extract (Nigella sativa) at a dose of $2000 \mathrm{mg} / \mathrm{kgBW} /$ day for $15 \mathrm{~d}$.

After that, monitoring of systolic blood pressure carried out every morning (8:00 to 10:00) and every three days. Black cumin (Nigella sativa) administration in groups 3 and 4 was given immediately after an increase in systolic blood pressure in rats. Black cumin (Nigella sativa) is given orally according to the dose of each group every day until the 15 th day. On the 16th day, the four groups were terminated.

\section{Statistical analysis}

Data will be presented in the form of mean and standard deviation if the data is normally distributed. If the data is not normally distributed, the data will be presented in quartile form. Data were processed and analyzed using SPSS with a significance limit of $\mathrm{p}<0.05$. To assess whether the sample is normally distributed or not the Shapiro-Wilk test was carried out because the sample was $\leq 50$. To assess the comparison of parameters (systolic and diastolic blood pressure, mean arterial pressure and proteinuria) between groups, the ANOVA test was used if the data were normally distributed and the Kruskal Wallis test if the data were not normally distributed.

\section{RESULTS}

In the research, experimental animals in the form of 24 white Rattus norvegicus female rats aged $10 \mathrm{w}$ had met the inclusion and exclusion criteria. Then divided into four groups.

\section{Characteristics of experimental animals}

Table 1: Trial distribution group

\begin{tabular}{lll}
\hline Group & F & \% \\
\hline Control-(C-) & 6 & 25.0 \\
Control+(C+) & 6 & 25.0 \\
Nigella Sativa 500 (T1) & 6 & 25.0 \\
Nigella Sativa 2000 (T2) & 6 & 25.0 \\
Total & 24 & 100.0 \\
\hline
\end{tabular}

Systolic and diastolic blood pressure after administration of black cumin extract (Nigella sativa) in preeclampsia model rats

From the results of this research, obtained systolic and diastolic blood pressure in the negative control group, positive control group, and the treatment group. Can be seen in the negative control group, blood pressure within the normal range obtained during monitoring. In the positive control group, there was an increase in systolic blood pressure during monitoring compared to the negative control group. This can be seen in fig. 1 . In the group of rats given black cumin extract showed a decrease in systolic blood pressure. This indicates a change in systolic blood pressure in experimental animals.

From fig. 1. it was found that blood pressure in treatment group 1 (P1) and group 2 (P2) showed a decrease in systole blood pressure. Systolic blood pressure decreased in preeclampsia models rats by administering black cumin extract with a dose of $500 \mathrm{mg}(\mathrm{P} 1)$ and $2000 \mathrm{mg}$ (P2). However, a dose of 2000 mg black cumin extract significantly decrease systolic blood pressure than $500 \mathrm{mg}$ black cumin extract.

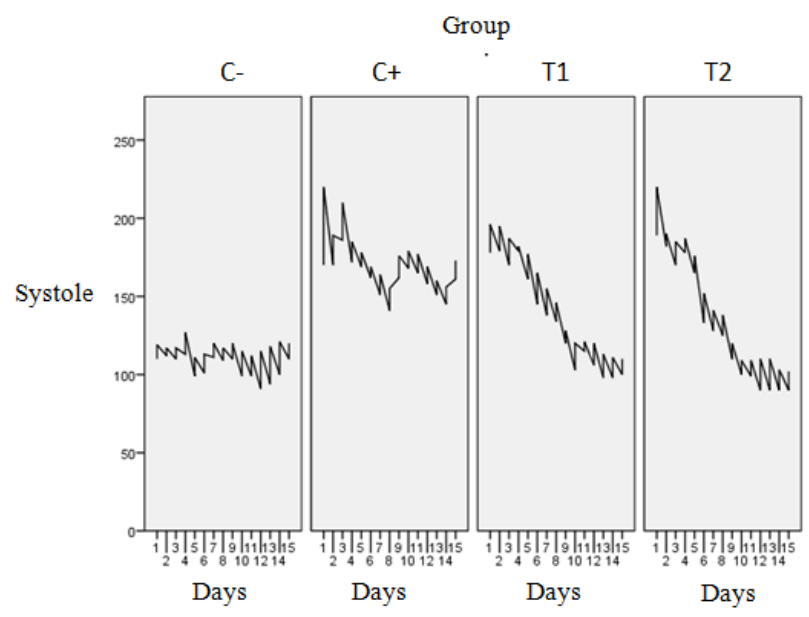

Fig. 1: Administration of black cumin extract can reduce systolic blood pressure in the case group, whereas the positive control group still shows an increase in systolic blood pressure 


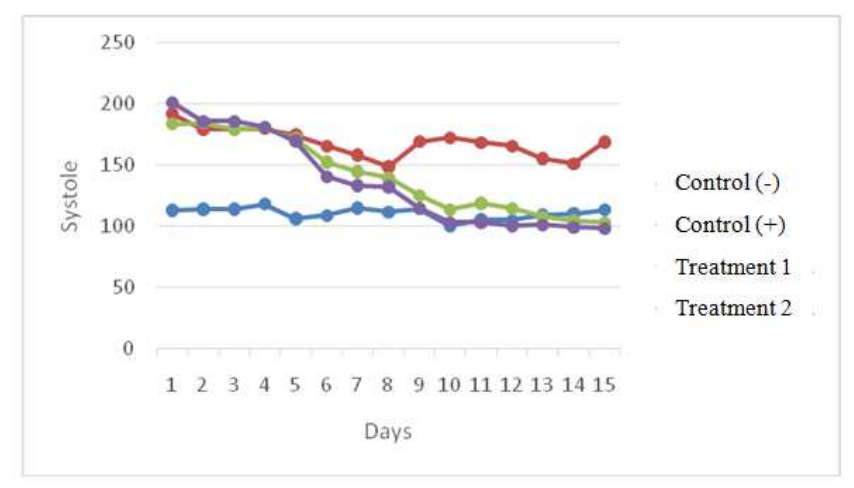

Fig. 2: Comparison of mean systole blood pressure between groups

From the fig. below, it can be seen the diastole blood pressure values in the treatment group 1 (P1) at a dose of $500 \mathrm{mg}$ and treatment group 2 (P2) at a dose of $2000 \mathrm{mg}$ experienced a decrease approaching the diastole value in normal rat group.

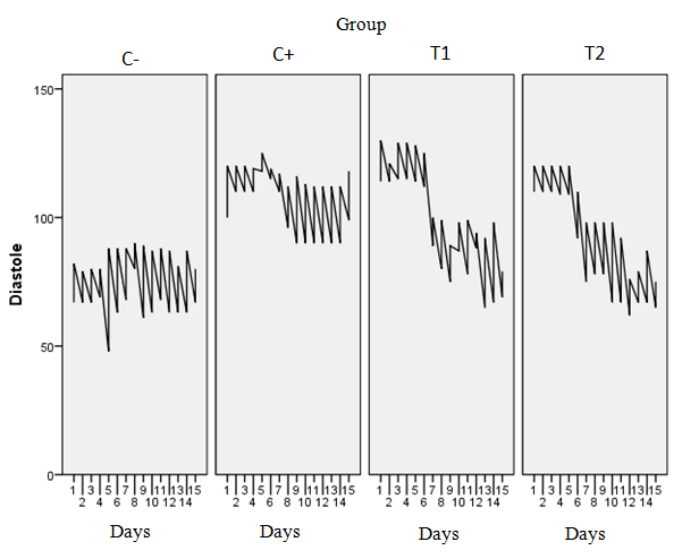

Fig. 3: The administration of black cumin extract (Nigella sativa) can reduce diastole blood pressure in the case group, approaching diastole blood pressure in the negative control group, while the negative control group still shows an increase in diastole blood pressure

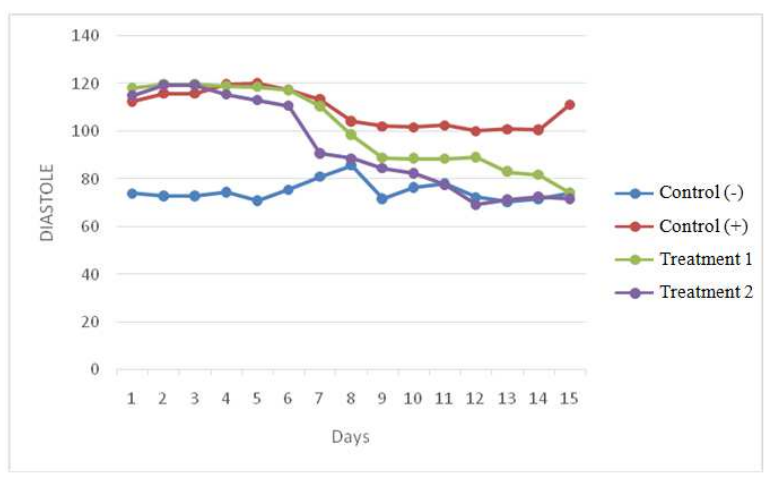

Fig. 4: Comparison of mean diastole between groups

Based on table 2 it was found that changes in blood pressure from the $1^{\text {st }}$ day to the $15^{\text {th }}$ day had a significant difference, where there was a significant difference in blood pressure values in the normal (C-) group and the preeclampsia $(\mathrm{C}+)$ group $(\mathrm{p}<0,000$, CI $95 \%$ 38.59-29.10); normal rat group with rat given $500 \mathrm{mg}$ black cumin extract groups $((\mathrm{p}<0,000, \mathrm{CI} 95 \%-34.06-21.49)$; normal rat groups with rat given $2000 \mathrm{mg}$ black cumin extract groups $(\mathrm{p}<0,000,95 \%$ CI-24.85-16.22) There was a significant difference in blood pressure in the rat with LPS injection group with a negative group $(p<0,000$, 95\% CI 29.10-37.17); Significant difference between the positive control group and rat given $500 \mathrm{mg}$ black cumin extract group
( $\mathrm{p}<0.058$, CI 95\%-0.19-38.59); there was a significant difference between the positive control group and rat given $2000 \mathrm{mg}$ black cumin extract group ( $\mathrm{p}<0,000,95 \%$ CI 9.07-12.33) There was a significant difference in rat given $500 \mathrm{mg}$ black cumin extract group with negative control group ( $\mathrm{p}<0,000,95 \%$ CI $21.49-34,06)$ there was no significant difference in blood pressure between rat given $500 \mathrm{mg}$ black cumin extract groups with a positive control group (p $=0.58,95 \%$ CI-12.33-0.19). There was found blood pressure difference in rat given $2000 \mathrm{mg}$ black cumin extract group with a positive control group ( $\mathrm{p}<0,000,95 \%$ CI 16.22-24.85); there was a difference in blood pressure in the rat group with black cumin dose 
2000 mg with negative control group ( $\mathrm{p}<0,000,95 \%$ CI-17.55-9.07); there was a difference in blood pressure in the rat given $2000 \mathrm{mg}$ black cumin extract and 500 mg black cumin extract group ( $\mathrm{p}=$ 0.022, 95\% CI-13.38-1.09).

Table 2: Comparison of mean values of blood pressure of mice

\begin{tabular}{|c|c|c|c|c|c|c|}
\hline \multirow[t]{2}{*}{ (I) klp } & \multirow[t]{2}{*}{ (J) klp } & \multirow[t]{2}{*}{ Mean difference (I-J) } & \multirow[t]{2}{*}{ Std. error } & \multirow[t]{2}{*}{ Sig. } & \multicolumn{2}{|c|}{ 95\% confidence } \\
\hline & & & & & Lower bound & Upper bound \\
\hline \multirow[t]{3}{*}{$C-$} & $\mathrm{C}+$ & $-33.85^{*}$ & 1.455 & .000 & -38.59 & -29.10 \\
\hline & $\mathrm{T} 1$ & $-27.77^{*}$ & 1.862 & .000 & -34.06 & -21.49 \\
\hline & $\mathrm{T} 2$ & $-20.54^{*}$ & 1.296 & .000 & -24.85 & -16.22 \\
\hline \multirow[t]{3}{*}{$C+$} & $\mathrm{C}-$ & $33.85^{*}$ & 1.455 & .000 & 29.10 & 37.17 \\
\hline & $\mathrm{T} 1$ & 6.07 & 1.849 & .058 & -.19 & 38.59 \\
\hline & $\mathrm{T} 2$ & $13.31^{*}$ & 1.276 & .000 & 9.07 & 12.33 \\
\hline \multirow[t]{3}{*}{$T 1$} & $\mathrm{C}-$ & $27.77^{*}$ & 1.862 & .000 & 21.49 & 34.06 \\
\hline & $\mathrm{C}+$ & -6.07 & 1.849 & .058 & -12.33 & .19 \\
\hline & $\mathrm{T} 2$ & $7.24^{*}$ & 1.726 & .022 & 1.09 & 13.38 \\
\hline \multirow[t]{3}{*}{$T 2$} & $\mathrm{C}+$ & $20.54^{*}$ & 1.296 & .000 & 16.22 & 24.85 \\
\hline & $\mathrm{C}-$ & $-13.31^{*}$ & 1.276 & .000 & -17.55 & -9.07 \\
\hline & $\mathrm{T} 1$ & $-7.24^{*}$ & 1.726 & .022 & -13.38 & -1.09 \\
\hline
\end{tabular}

Comparison of mean arterial pressure (MAP) after black cumin extract administration

Based on table 3. it was found that MAP change from the $1^{\text {st }}$ day to the $15^{\text {th }}$ day had a significant difference, where there were significant differences in blood pressure values in normal (C-) group and the preeclampsia $(\mathrm{C}+$ ) group ( $\mathrm{p}<0.001$, CI 95\%-46.35-37.48); normal rat group with rat given $500 \mathrm{mg}$ black cumin extract groups $((\mathrm{p}<0,000, \mathrm{CI}$ 95\%-33.74-23.41); normal rat group with rat given $2000 \mathrm{mg}$ black cumin extract groups ( $\mathrm{p}<0.001$, CI $95 \%-25.70-17.83$ ) There was a significant difference in blood pressure in the rat given LPS injection group with rat given500 mg black cumin extract groups $(\mathrm{p}<0.001$, 95\% CI 8.12-18.55); there was a significant difference between the positive control group and rat given $2000 \mathrm{mg}$ black cumin group ( $\mathrm{p}<0.001,95 \%$ CI 16.11-24.18); there was a significant difference between the positive control group and the negative control group $(\mathrm{p}<0.001,95 \%$ CI 23.4-33.74) There was a significant difference in rat given $500 \mathrm{mg}$ black cumin extract group with a positive control group ( $\mathrm{p}<0.001,95 \%$ CI-18.55-8.12); there was a significant difference on blood pressure between rat given500 mg black cumin extract groups with rat given $2000 \mathrm{mg}$ black cumin extract group $(\mathrm{p}<0.001,95 \% \mathrm{CI}$ 1.85-11.76); there was a significant difference between rat given 500 mg black cumin extract groups and negative control group $(\mathrm{p}<0.001$, 95\% CI 17.83-25.70). There was a difference in blood pressure in the rat given $2000 \mathrm{mg}$ black cumin extract group with positive control group ( $<<0.001$, CI 95\%-24.18-16.11).

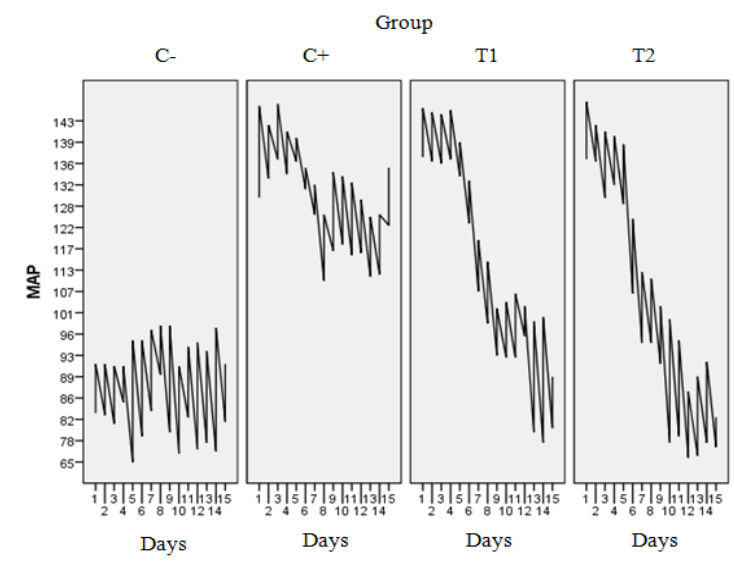

Fig. 5: Comparison of MAP between groups

Table 3: Comparison of mean arterial pressure (MAP) value in model mice

\begin{tabular}{|c|c|c|c|c|c|c|}
\hline \multirow[t]{2}{*}{ (I) klp } & \multirow[t]{2}{*}{ (J) klp } & \multirow[t]{2}{*}{ Mean difference (I-J) } & \multirow[t]{2}{*}{ Std. error } & \multirow[t]{2}{*}{ Sig. } & \multicolumn{2}{|c|}{ 95\% confidence } \\
\hline & & & & & Lower bound & Upper bound \\
\hline \multirow[t]{3}{*}{$C-$} & $\mathrm{C}+$ & $-41,92$ & 1,35 & $<0.0001$ & $-46,35$ & $-37,48$ \\
\hline & $\mathrm{T} 1$ & 28,57 & 1,57 & $<0.0001$ & $-33,74$ & $-23,41$ \\
\hline & $\mathrm{T} 2$ & $-21,76$ & 1,18 & $<0.0001$ & $-25,70$ & $-17,83$ \\
\hline \multirow[t]{3}{*}{$C+$} & $\mathrm{C}-$ & 41,92 & 1,35 & $<0.0001$ & 37,48 & 46,35 \\
\hline & $\mathrm{T} 1$ & 13,34 & 1,57 & $<0.0001$ & 8,12 & 18,55 \\
\hline & $\mathrm{T} 2$ & 20,15 & 1,21 & $<0.0001$ & 16,11 & 24,18 \\
\hline \multirow[t]{3}{*}{$T 1$} & $\mathrm{C}-$ & 28,57 & 1,55 & $<0.0001$ & 23,4 & 33,74 \\
\hline & $\mathrm{C}+$ & $-12,34$ & 1,57 & $<0.0001$ & $-18,55$ & $-8,12$ \\
\hline & $\mathrm{T} 2$ & 6,80 & 1,43 & $<0.0001$ & 1,85 & 11,76 \\
\hline \multirow[t]{3}{*}{$T 2$} & $\mathrm{C}-$ & 21,76 & 1,18 & $<0.0001$ & 17,83 & 25,70 \\
\hline & $\mathrm{C}+$ & $-20,15$ & 1,21 & $<0.0001$ & $-24,18$ & $-16,11$ \\
\hline & $\mathrm{T} 1$ & $-6,81$ & 1,43 & $<0.0001$ & $-11,76$ & $-1,85$ \\
\hline
\end{tabular}


From the image below it can be seen the mean MAP comparison in each group of rats. This results showed MAP decrease in rat given $500 \mathrm{mg}$ and
2000 mg black cumin extract. However, a more significant decrease in MAP was seen in rat given 2000 mg black cumin extract.

\section{Comparison of proteinuria in each study group}

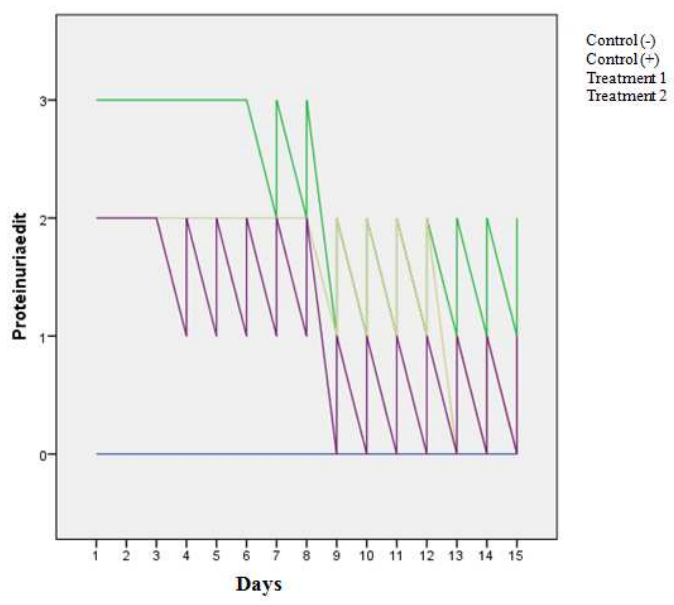

Fig. 6: Comparison of proteinuria in each group

In fig. 6, Proteinuria shows a decrease per day where it appears the role of black cumin can reduce protein in the urine.

Table 4: Proteinuria in the study group from day 1 to day 15

\begin{tabular}{|c|c|c|c|c|c|c|c|c|c|c|c|c|c|c|c|c|c|c|c|c|c|c|c|c|c|c|c|c|c|c|c|}
\hline & & \multicolumn{30}{|c|}{ Proteinuria } \\
\hline & & \multicolumn{2}{|c|}{1} & \multicolumn{2}{|c|}{2} & \multicolumn{2}{|l|}{3} & \multicolumn{2}{|l|}{4} & \multicolumn{2}{|l|}{5} & \multicolumn{2}{|l|}{6} & \multicolumn{2}{|l|}{7} & \multicolumn{2}{|l|}{8} & \multicolumn{2}{|l|}{9} & \multicolumn{2}{|l|}{10} & \multicolumn{2}{|c|}{11} & \multicolumn{2}{|c|}{12} & \multicolumn{2}{|c|}{13} & \multicolumn{2}{|c|}{14} & \multicolumn{2}{|l|}{15} \\
\hline & & $\mathbf{n}$ & $\%$ & $\mathbf{N}$ & $\%$ & $\mathbf{n}$ & $\%$ & $\mathbf{N}$ & $\%$ & $\mathbf{n}$ & $\%$ & $\mathbf{n}$ & $\%$ & $\mathbf{n}$ & $\%$ & $\mathbf{n}$ & $\%$ & $\mathbf{n}$ & $\%$ & $\mathbf{n}$ & $\%$ & $\mathbf{n}$ & $\%$ & $\mathbf{n}$ & $\%$ & $\mathbf{n}$ & $\%$ & $\mathbf{n}$ & $\%$ & $\mathbf{n}$ & $\%$ \\
\hline $\mathrm{C}$ & - & 6 & 1 & 6 & 10 & 6 & 10 & 6 & 10 & 6 & 10 & 6 & 10 & 6 & 10 & 6 & 10 & 6 & 10 & 6 & 10 & 6 & 10 & 6 & 10 & 6 & 10 & 6 & 10 & 6 & 1 \\
\hline \multirow[t]{4}{*}{-} & & & $\begin{array}{l}0 \\
0\end{array}$ & & 0 & & 0 & & 0 & & 0 & & 0 & & 0 & & 0 & & 0 & & 0 & & 0 & & 0 & & 0 & & 0 & & $\begin{array}{l}0 \\
0\end{array}$ \\
\hline & $\begin{array}{l}+ \\
1\end{array}$ & 0 & 0 & 0 & 0 & 0 & 0 & 0 & 0 & 0 & 0 & 0 & 0 & 0 & 0 & 0 & 0 & 0 & 0 & 0 & 0 & 0 & 0 & 0 & 0 & 0 & 0 & 0 & 0 & 0 & 0 \\
\hline & + & 0 & 0 & 0 & 0 & 0 & 0 & 0 & 0 & 0 & 0 & 0 & 0 & 0 & 0 & 0 & 0 & 0 & 0 & 0 & 0 & 0 & 0 & 0 & 0 & 0 & 0 & 0 & 0 & 0 & 0 \\
\hline & $\begin{array}{l}+ \\
3\end{array}$ & 0 & 0 & 0 & 0 & 0 & 0 & 0 & 0 & 0 & 0 & 0 & 0 & 0 & 0 & 0 & 0 & 0 & 0 & 0 & 0 & 0 & 0 & 0 & 0 & 0 & 0 & 0 & 0 & 0 & 0 \\
\hline $\mathrm{C}$ & - & 0 & 0 & 0 & 0 & 0 & 0 & 0 & 0 & 0 & 0 & 0 & 0 & 0 & 0 & 0 & 0 & 0 & 0 & 0 & 0 & 0 & 0 & 0 & 0 & 0 & 0 & 0 & 0 & 0 & 0 \\
\hline \multirow[t]{3}{*}{+} & $\begin{array}{l}+ \\
1\end{array}$ & 0 & 0 & 0 & 0 & 0 & 0 & 0 & 0 & 0 & 0 & 0 & 0 & 0 & 0 & 0 & 0 & 2 & $\begin{array}{l}33 \\
.3\end{array}$ & 2 & $\begin{array}{l}33 \\
.3\end{array}$ & 2 & $\begin{array}{l}33 \\
.3\end{array}$ & 2 & $\begin{array}{l}33 \\
.3\end{array}$ & 2 & $\begin{array}{l}33 \\
.3\end{array}$ & 2 & $\begin{array}{l}33 \\
.3\end{array}$ & 0 & 0 \\
\hline & $\begin{array}{l}+ \\
2\end{array}$ & 0 & 0 & 0 & 0 & 0 & 0 & 0 & 0 & 0 & 0 & 0 & 0 & 2 & $\begin{array}{l}33 \\
.3\end{array}$ & 3 & 50 & 4 & $\begin{array}{l}66 \\
.7\end{array}$ & 4 & $\begin{array}{l}66 \\
.7\end{array}$ & 4 & $\begin{array}{l}66 \\
.7\end{array}$ & 4 & $\begin{array}{l}66 \\
.7\end{array}$ & 4 & $\begin{array}{l}66 \\
.7\end{array}$ & 4 & $\begin{array}{l}66 \\
.7\end{array}$ & 6 & $\begin{array}{l}1 \\
0 \\
0\end{array}$ \\
\hline & $\begin{array}{l}+ \\
3\end{array}$ & 6 & $\begin{array}{l}1 \\
0 \\
0\end{array}$ & 6 & $\begin{array}{l}10 \\
0\end{array}$ & 6 & $\begin{array}{l}10 \\
0\end{array}$ & 6 & $\begin{array}{l}10 \\
0\end{array}$ & 6 & $\begin{array}{l}10 \\
0\end{array}$ & 6 & $\begin{array}{l}10 \\
0\end{array}$ & 4 & $\begin{array}{l}66 \\
.7\end{array}$ & 3 & 50 & 0 & 0 & 0 & 0 & 0 & 0 & 0 & 0 & 0 & 0 & 0 & 0 & 0 & 0 \\
\hline $\mathrm{T}$ & - & 0 & 0 & 0 & 0 & 0 & 0 & 0 & 0 & 0 & 0 & 0 & 0 & 0 & 0 & 0 & 0 & 0 & 0 & 0 & 0 & 0 & 0 & 0 & 0 & 0 & 0 & 0 & 0 & 0 & 0 \\
\hline \multirow[t]{3}{*}{1} & + & 0 & 0 & 0 & 0 & 0 & 0 & 0 & 0 & 0 & 0 & 0 & 0 & 0 & 0 & 0 & 0 & 0 & 0 & 0 & 0 & 0 & 0 & 0 & 0 & 0 & 0 & 0 & 0 & 0 & 0 \\
\hline & $\begin{array}{l}+ \\
2\end{array}$ & 6 & $\begin{array}{l}1 \\
0 \\
0\end{array}$ & 6 & $\begin{array}{l}10 \\
0\end{array}$ & 6 & $\begin{array}{l}10 \\
0\end{array}$ & 6 & $\begin{array}{l}10 \\
0\end{array}$ & 6 & $\begin{array}{l}10 \\
0\end{array}$ & 6 & $\begin{array}{l}10 \\
0\end{array}$ & 6 & $\begin{array}{l}10 \\
0\end{array}$ & 6 & $\begin{array}{l}10 \\
0\end{array}$ & 6 & $\begin{array}{l}10 \\
0\end{array}$ & 6 & $\begin{array}{l}10 \\
0\end{array}$ & 6 & $\begin{array}{l}10 \\
0\end{array}$ & 6 & $\begin{array}{l}10 \\
0\end{array}$ & 6 & $\begin{array}{l}10 \\
0\end{array}$ & 6 & $\begin{array}{l}10 \\
0\end{array}$ & 6 & $\begin{array}{l}1 \\
0 \\
0\end{array}$ \\
\hline & $\begin{array}{l}+ \\
3\end{array}$ & 0 & 0 & 0 & 0 & 0 & 0 & 0 & 0 & 0 & 0 & 0 & 0 & 0 & 0 & 0 & 0 & 0 & 0 & 0 & 0 & 0 & 0 & 0 & 0 & 0 & 0 & 0 & 0 & 0 & 0 \\
\hline \multirow[t]{4}{*}{$\begin{array}{l}\mathrm{T} \\
2\end{array}$} & - & 0 & 0 & 0 & 0 & 0 & 0 & 0 & 0 & 0 & 0 & 0 & 0 & 0 & 0 & 0 & 0 & 2 & $\begin{array}{l}33 \\
.3\end{array}$ & 2 & $\begin{array}{l}33 \\
.3\end{array}$ & 2 & $\begin{array}{l}33 \\
.3\end{array}$ & 2 & $\begin{array}{l}33 \\
.3\end{array}$ & 2 & $\begin{array}{l}33 \\
.3\end{array}$ & 2 & $\begin{array}{l}33 \\
.3\end{array}$ & 6 & $\begin{array}{l}1 \\
0\end{array}$ \\
\hline & $\begin{array}{l}+ \\
1\end{array}$ & 0 & 0 & 2 & $\begin{array}{l}33 \\
.3\end{array}$ & 1 & $\begin{array}{l}16 \\
.7\end{array}$ & 1 & $\begin{array}{l}16 \\
.7\end{array}$ & 1 & $\begin{array}{l}16 \\
.7\end{array}$ & 1 & $\begin{array}{l}16 \\
.7\end{array}$ & 1 & $\begin{array}{l}16 \\
.7\end{array}$ & 1 & $\begin{array}{l}16 \\
.7\end{array}$ & 3 & 50 & 3 & 50 & 3 & 50 & 3 & 50 & 3 & 50 & 3 & 50 & 0 & 0 \\
\hline & + & 6 & $\begin{array}{l}1 \\
0 \\
0\end{array}$ & 4 & $\begin{array}{l}66 \\
.7\end{array}$ & 5 & $\begin{array}{l}83 \\
.3\end{array}$ & 5 & $\begin{array}{l}83 \\
.3\end{array}$ & 5 & $\begin{array}{l}83 \\
.3\end{array}$ & 5 & $\begin{array}{l}83 \\
.3\end{array}$ & 5 & $\begin{array}{l}83 \\
.3\end{array}$ & 5 & $\begin{array}{l}83 \\
.3\end{array}$ & 1 & $\begin{array}{l}16 \\
.7\end{array}$ & 1 & $\begin{array}{l}16 \\
.7\end{array}$ & 1 & $\begin{array}{l}16 \\
.7\end{array}$ & 1 & $\begin{array}{l}16 \\
.7\end{array}$ & 1 & $\begin{array}{l}16 \\
.7\end{array}$ & 1 & $\begin{array}{l}16 \\
.7\end{array}$ & 0 & 0 \\
\hline & $\begin{array}{l}+ \\
3\end{array}$ & 0 & 0 & 0 & 0 & 0 & 0 & 0 & 0 & 0 & 0 & 0 & 0 & 0 & 0 & 0 & 0 & 0 & 0 & 0 & 0 & 0 & 0 & 0 & 0 & 0 & 0 & 0 & 0 & 0 & 0 \\
\hline
\end{tabular}

\section{DISCUSSION}

Changes of mean systole in preeclampsia by administration of black cumin extract (Nigella sativa)

The results of this study are in line with the study of Jarin et al., 2015 in which the administration of a combination of black cumin extract
(Nigella Sativa) and nicardipine showed a significant decrease in systolic blood pressure. A decrease in systolic blood pressure with Nigella sativa was also followed by a significant decrease in MDA, ACE, NADPH oxidase activity and increased activity of HO-1 in cardiac, which was also accompanied by an increase in plasma NO [13]. 
The antioxidant effect of Nigella Sativa is also often reported lately. Antioxidant effect of Nigela Sativa which contributes to the antihypertensive effect. Apart from its antioxidant activity, the blood pressure reduction effect of Nigella Sativa can be caused by ant diuretic, anti-inflammatory, or protective effects on the kidneys $[14,15]$.

Endothelium has an important role in vascular muscle relaxation, where several studies have confirmed the involvement of the role of blood vessels as part of the pathophysiology of hypertension [16]. Nigella Sativa extract dose of $30 \mathrm{mg} / \mathrm{ml}$ can produce vasorelaxant effects of blood vessels. Thus, Nigella Sativa extract works the same as a blood vessel relaxant factor (Nitrite oxidant or prostacyclin) which causes vasodilation [17].

Previous studies also reported that essential oils from black cumin and thymoquinone lowered blood pressure and heart rate, both directly and indirectly through mechanisms that act as serotoninergic and muscarinic receptors. Thymol, the active component of Nigella Sativa, is known to have a role and can reduce blood pressure through work on calcium ion channels. Peixoto et al. reported that thymol produced a relaxing effect in aortic mice [18].

Changes of mean diastole in preeclampsia by administration of black cumin extract (Nigella sativa)

Based on research conducted by Huseini et al., 2013 it was found that consumption of $5 \mathrm{ml}$ of Nigella sativa every day can reduce diastolic by decreasing $12.46 \%$. This was also done by Indrawan et al. in 2016, they found that a significant difference was found in endothelin 1 (ET-1) levels in rats with preeclampsia. Reduction of ET-1 by black cumin (Nigella sativa) can reduce levels of ET- 1 by inhibiting the formation of peroxynitrite, which can reduce endothelial dysfunction [9].

According to the study of Sahebkar et al., 2016 daily consumption of Nigella Sativa dose of $5 \mathrm{ml}$ can reduce blood pressure both systole and diastole in normal patients without any accompanying effects on the liver and kidneys. Obtained a decrease in systolic blood pressure $(8.17 \%)$ and a decrease in systolic blood pressure $(12.46 \%)$. Another mechanism that occurs as a blood pressure reduction effect is the diuresis effect of Nigella Sativa, from a dose of $0.6 \mathrm{ml} / \mathrm{kg}$ for $15 \mathrm{~d}$ can cause increase in diuresis about $16 \%$ spontaneously in hypertensive rats. The diuresis effect of Nigella Sativa compared to $5 \mathrm{mg} / \mathrm{kg}$ of furosemide which has a strong diuresis effect associated with excretion of $\mathrm{Na}, \mathrm{K}, \mathrm{Cl}$, and urine. The results of this study mention that Nigella Sativa can reduce blood pressure through the effects of diuresis, decreased water and electrolytes which cause blood volume, cardiac output and as a main regulation of blood pressure [19].

\section{Change in mean MAP in preeclampsia by administering black cumin extract (Nigella sativa)}

Black cumin has been known to have many benefits, such as antiinflammatory, antioxidant, and antihypertensive. Black cumin can play a role in protecting organs from damage due to oxidative stress. The content of timoquinone in black cumin acts as an anti-inflammatory by inhibiting pro-inflammatory cytokines and Nuclear Factor Kappa Beta (NF-kB) transcription factors [20]. The effect of a decrease in blood pressure associated with a decrease in cardiac lipid peroxidation products and inhibition of the activity of the angiotensin converting enzyme was seen in samples receiving $\mathrm{N}$. sativa oil followed by significantly higher plasma nitric oxide levels compared to the placebo group or those receiving nicardipine. Black cumin and its active component, thymoquinone, reduce oxidative stress through calcium channel blockade and increase urine output activity that may be associated with a decrease in blood pressure [21].

Previous studies assessing the dose of N. sativa (300 mg twice daily for $4 \mathrm{w}$ ) with the severity of hypertension showed patients at a dose of $200 \mathrm{mg}$ twice daily for $4 \mathrm{w}$ and $500 \mathrm{mg}$ twice daily for $6 \mathrm{w}$, respectively, showing significant systolic decrease [22]. Research conducted by Hebil et al. in which intravenous injection of Nigella sativa extract doses of $50,100,200 \mathrm{mg} / \mathrm{kg}$ showed a decrease in mean arterial pressure (MAP) $(\mathrm{p}<0.001)$ followed by a significant decrease in blood pressure $(p<0.001)$ [17]. The central nervous system plays an important role in the rapid control of arterial blood pressure. Thus, the observed decrease in arterial blood pressure may be caused by inhibition of the sympathetic nervous system that can control the aorta under normal conditions [16].

\section{Changes of proteinuria in preeclampsia by administration of black cumin extract (Nigella sativa)}

In recent years, clinical and experimental studies of Nigella Sativa extract have shown many therapeutic effects. In addition, recent toxicological studies have shown that crude extracts of seeds and some of their active constituents (essential oils and Thymoquinone) may have a protective effect on nephrotoxicity. Data can also indicate that Thymoquinone might act as a protective agent for proteinuria and hyperlipidemia associated with nephrotic syndrome [23].

\section{CONCLUSION}

Black cumin (Nigella sativa) is one type of plant that has many properties. It has long been known that black cumin has many benefits, both as an anti-inflammatory, antioxidant, and antihypertensive. The active ingredients in the form of thymoquinone, dithymoquinone, and thymol have many uses. Black cumin is also known as a cure for all kinds of diseases. With the results of this study, black cumin can be recommended to be given to pregnant women both at risk and not, to prevent the occurrence of preeclampsia, given the side effects that do not exist. Black cumin is proven to reduce systolic and diastolic blood pressure, Mean Arterial Pressure and proteinuria.

\section{ACKNOWLEDGEMENT}

The researcher show gratitude for all the staffobstetric and gynecology departments involved and the research samples who participated in this research.

\section{FUNDING}

Nil

\section{AUTHORS CONTRIBUTIONS}

All the authors have contributed equally.

\section{CONFLICT OF INTERESTS}

Declared none

\section{REFERENCES}

1. Kementerian Kesehatan Republik Indonesia. Survei Demografi dan Kesehatan Indonesia. Pusat Data dan Informasi Kementerian Kesehatan Republik Indonesia; 2018.

2. Achadi EL. Kematian maternal dan neonatal di Indonesia. FKM UI; 2019.

3. Amaral LM, Cunningham MW, Cornelius DC, LaMarca B. Preeclampsia: long-term consequences for vascular health, Vasc. Health Risk Manag 2015;11:403-15.

4. World Health Organization. WHO recommendations for prevention and treatment of pre-eclampsia and eclampsia; 2011.

5. Manik IN, Sari RDP, Wulan AJ. Hubungan status preeklampsia dengan kejadian perdarahan postpartum pada ibu bersalin di RSUD dr h abdul moeloek provinsi lampung periode 1 Jul 201430 Jun 2015. J Majority 2017;6:51-7.

6. Doshi SB, Agarwal A. The role of oxidative stress in menopause. J Midlife Health 2013;4:140-6.

7. MFG Siregar, Siburian PS, Kaban YB, Siregar HS, Effendi IH, Rivani $R$. The differences of catalase enzyme level between menopause andreproductive women. Giorn It Ost Gin 2015;XXXVII:6.

8. Bahareh A, Hossein H. Black cumin (Nigella sativa) and its active constituent, thymoquinone: an overview on the analgesic and anti-inflammatory effects. Planta Med 2016;82:8-16

9. Shahraki S, Khajavirad A, Shafei MN, Mahmoudi M, Tabasi NS. Effect of total hydroalcholic extract of Nigella sativa and its nhexane and ethyl acetate fractions on ACHN and GP-293 cell lines. J Tradit Complement Med 2016;6:89-96.

10. Gong P, Liu M, Hong G, Li Y, Xue P, Zheng M, et al. Curcumin improves LPS-induced preeclampsia-like phenotype in rat by inhibiting the TLR4 signaling pathway. Placenta 2016;41:45-52.

11. Pennington KA, Schlitt JM, Jackson DL, Schulz LC, Schust DJ. Preeclampsia: multiple approachs for a multifactorial disease. Dis Model Mech 2012;5:9-18. 
12. Leong XF, Rais Mustafa $M$, Jaarin K. Nigella sativa and its protective role in oxidative stress and hypertension. Evid Based Complementary Altern Med 2013. https://doi.org/10.1155/2013/120732

13. Jaarin K, Foong WD, Yeoh MH, Kamarul ZYN, Qodriyah HMS. Mechanism of the anti-hypertensive effect of Nigella sativa oil in L-NAME induced hypertensive rats. Clinics 2015;70:751-7.

14. Alagawany M, Farag MR, Tiwari R, Karthik K, Dhama K. Nutritional, healthical and therapeutic efficacy of black cumin (Nigella sativa) in animals, poultry and humans. Int J Pharmacol 2016;12:232-48.

15. El-Sherbiny SS, El-Tamany ESH, El-Maksoud A. Protective effect of allium sativum and nigella sativa against no-mediated alterations in dimethylhydrazine-induced colon cancer rats. Egypt J Hosp Med 2004;15:1-14.

16. Adeneye A, Eddouks M. Phytotherapy in the management of diabetes and hypertension. In book: Phytotherapy of hypertension and diabetes mellitus. ed. 1st edition. Bentham Science Publishers; 2016. p. 131-63.

17. Hebi M, Zeggwagh N, Hajj L, El Bouhali B, Eddouks M. Cardiovascular effect of Nigella sativa L. aqueous extract in normal rats. Cardiovascular and Haematological Disorders Drug Targets 2016;16:47-55.

18. Peixoto Neves D, Silva Alves KS, Gomes MDM, Lahlou S, Magalhaes PJ. Vasorelaxant effects of the monoterpenic phenol isomers, carvacrol and thymol, on rat isolated aorta. Fundamental Clin Pharmacol 2010;24:341-50.

19. Sahebkar A, Soranna D, Liu X, Thomopoulos C, Simental Mendia LE, et al. A systematic review and meta-analysis of randomized controlled trials investigating the effects of supplementation with Nigella sativa (black seed) on blood pressure. J Hypertens 2016;34:2127-35.

20. Rahma H, Indrawan IWA, Nooryanto M. Effect of a black cumin (Nigella sativa) ethanol extract on placental angiotensin II type 1-receptor autoantibody (AT1-AA) serum levels and endothelin-1 (ET-1) expression in a preeclampsia mouse model. J Taibah Univ Med Sci 2017;12:528.

21. Yimer EM, Tuem KB, Karim A, Ur Rehman N, Anwar F. Nigella sativa L. (black cumin): a promising natural remedy for wide range of illnesses. Evid Based Complementary Altern Med 2019;54:671-8.

22. Zainiyah H, Noviani NW, Hipni R. The positive efect of black cumin ethanol extract (Nigella sativa) on decreasing serum TNF-alpha levels and interleukin- 8 in mice of preeclampsia. Biomed Res 2018;29:3801-6.

23. Badary OA, Abdel Naim AB, Abdel Wahab MH, Hamada FM. The influence of thymoquinone on doxorubicin-induced hyperlipidemic nephropathy in rats. Toxicology 2000;143:21926. 